コール酸にはこのような現象はみられない。また分㒭の度合は水 酸基の数が多いほど大きいものと考元られる。

また，二つの界面活性物質が同時に存在するときどちらが吸着 力の強い方だけが吸着するという従来の結果に反して，両者が協 調して吸着する場合もあることがわかった。これは脱着電位がた がいに接近しているほど協調吸着しやすく，離れているほど吸着 力の強い方が独占して吸着しやすくなる。また DOC-メチルセ
ルロース系の場合のように, 両者が独立した吸着層を形成して, 両者の独立したテンサンメトリー波が現われる場合もある。

デヒドロコール酸は純粋な拡散支配のテンサンメトリ一波を示 すが, DOG およびコール酸のテンサンメトリー波は分子中に含 まれる水酸基に基うく活性化吸着過程を含んでいる。

(1966 年 4 月，日本化学会第 19 年会発表)

\title{
光学活性アクリロイル-a-アミノ酸メチルエステルのオスミゥム酸エステルの旋光分散*
}

（昭和 42 年 3 月 3 日 受 理 )

\author{
迫 田 直一稲 則 夫*2
}

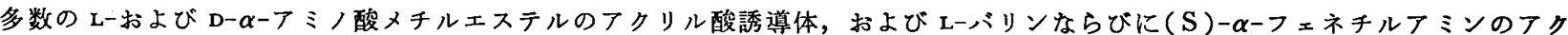
リル酸誘導体を合成した。これらモノ不飽和化合物のオスミウム酸エステル(ピリジン $2 \mathrm{~mol}$ の付加物)をつくってその旋光分散曲 線を測定した結果, 対応する円二色性との関連性からオスミウム酸エステルの旋光分散曲線はいずれも可視領域に複合 Cotton 効 果を示し，590と $460 \mathrm{~m} \mu$ 付近とに中心を有する二つの Cotton 勃果から生じていることが明らかとなった。そしてとの Cotton 効果曲線は背景曲線の影響を受けるととが少なく，その符号はただ一つの例外を除いて L-系では負，D-系では正であって $\boldsymbol{\alpha}$-不整 炭素の絶対配置と関係づけることができる。
\end{abstract}

\section{1 緒凅}

光学活性不飽和化合物の二重結合に適当な発色団を導入し，旋 光分散曲線の測定に都合のよい波長領域に Cotton 効果を生じさ せる方法として，エピスルフィド，トリチオカルボナート1，才 スミウム酸エステル2)などの誘導体にすることが報告されてい る。ことにオスミウム酸エステル法はコレステン類に用いて有効 なことが知られているが，その Cotton 効果と絶対配置との関係 については明らかにされていない。そこで著者らは不整炭素 1 個 を含んだ光学活性モノ不飽和化合物として種々の光学活性アクリ ロイルアミノ酸メチルエステルを合成し，そのオスミウム酸エス テル(ピリジン $2 \mathrm{~mol}$ の付加物)の Cotton 効果の符号とアミ， 酸の不整炭素の絶対配置との関係を明らかにしょうと試みた。

\section{2 実験}

\section{1 試 薬}

アミノ酸はいずれも米山薬品工業株式会社製を用いた。比旋光 度の值は $(c=2,6 \mathrm{~N}$ 塭酸)で測定した。
$\mathbf{L}-\boldsymbol{P} \quad$ ラ $=$ ン: $[\alpha]_{\mathrm{D}}^{8.5}+14.9^{\circ}$
L-バリリ ン: $[\alpha]_{\mathrm{D}}^{9.0}+28.5^{\circ}$
L-口 イ シ ン: $[\alpha]_{\mathrm{D}}^{23.2}+16.0^{\circ}$
D-口 1 シ ン: $[\alpha]_{\mathrm{D}}^{10.0}-14.7^{\circ}$

*1この報交を“旋光分散に関する研究(第 1 報)”とする.

*2 Naokazu SAKOTA, Norio KoINE 愛媛大学工学部工業 化学教室, 松山市交京町

1) G. Djerassi, H. Wolf, D. A. Lightner, E. Bunnenberg, T. Takeda, T. Komeno, K. Kuriyama, Tetrahedron, 19, 1547(1963).

2) E. Bunnenberg, C. Djerassi, J. Am. Chem. Soc., 82, 5953(1960).

$$
\begin{aligned}
& \text { L-イソロイシン: }[\alpha]_{\mathrm{D}}^{23.0}+39.0^{\circ}
\end{aligned}
$$

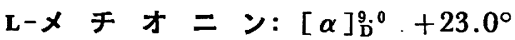

$$
\begin{aligned}
& \text { D-フェニルグリシン： }[\alpha]_{\mathrm{D}}^{20.0}-162.5^{\circ} \\
& \text { L-フェニルアラニン: }[\alpha]_{D}^{10.0}-8.5^{\circ} \\
& \text { D-フェニルアラニン: }[\alpha]_{D}^{10.0}+7.0^{\circ}
\end{aligned}
$$

(S) $-\alpha$-フェネチルアミン: $[\alpha]_{D}^{24.0}-32.8^{\circ}(l=1$, 無溶媒) で, 光学純度は約 $85 \%$ である。 bp $187^{\circ} \mathrm{C}_{0}$

酸化オスミウム(VII)：米山薬品工業社製, 純度 $99.7 \%$ 以上。 ピリジン：試薬一級品を酸化バリウムとともに蒸留して bp $114^{\circ} \sim 115^{\circ} \mathrm{G}$ の留分をとり水素化カルシウムで脱水後使用した。

エチルエーテル：試薬一級品を金属ナトリウムで乾燥後蒸留 し，使用直前に活性アルミナカラムで精製してオスミウム酸エス テルの合成に使用した。

酢酸エチル：試薬一級品を $5 \%$ 炭酸ナトリウム水溶液，つき に飽和塩化カルシウム水溶液で洗浄し, 無水炭酸ナトリウムで乾 燥後蒸留して bp $76^{\circ} \sim 77^{\circ} \mathrm{C}$ の留分をとりオスミウム酸エステル の合成に使用した。

メタノール：試薬特級品をそのまま使用した。

\section{2 アミノ酸メチルエステル塩酸塩の合成}

Schwarz らの方法にしたがってアミノ酸, 塭化チオニルおよ びメタノールから合成した。得られた結晶はメタノールーエチル エーテルの混合溶媒で 2〜3 回再結晶を行なったのち,つぎのア シル化に使用した。

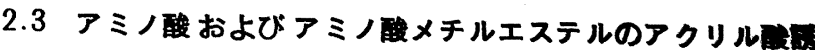

\section{尊体の合成}

2.3.1 アクリロイル-L-バリン (Acr・L-Val•OH)の合成: アク リル酸と塩化ベンゾイルから合成した塩化アクリロイル(bp $74^{\circ}$

3) H. Schwarz, F. M. Bumpus, I. H. Page, J. Am. Chem. Soc., 79, 5697(1951). 
〜 75C)を用い，Kulkarini らのの片法にしたがって L-バリン をアシル化した。得られた Acr.L-Val. OH は mp 118〜118.5

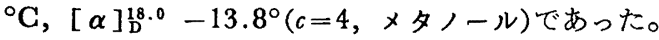
分析值 C $56.11 \%, \mathrm{H} 7.78 \%, \mathrm{~N} 8.43 \%$

$\mathrm{C}_{8} \mathrm{H}_{13} \mathrm{NO}_{3}$ としての

計算值 C $56.11 \%, \mathrm{H} 7.66 \% ， \mathrm{~N} 8.19 \%$

2.3.2 アクリロイルアミノ酸メチルエステルの合成: 2.3.1 の 方法に準じてつぎのようにして合成した。すなわちトリエチルア ミン $3.1 \mathrm{~g}(0.03 \mathrm{~mol})$ を含む水 $10 \mathrm{ml}$ にアう酸メチルエステ ル塩酸塩 $0.03 \mathrm{~mol}$ を溶解し, 氷冷下に塭化アクリロイル $3.0 \mathrm{~g}$ $(0.033 \mathrm{~mol})$ と $3 \mathrm{~N}$ 水酸化ナトリウム溶液 $11 \mathrm{ml}(0.033 \mathrm{~mol})$ とを 同時に滴下する。滴下終了後さらに 2 時間かきまぜたのち， $5 \mathrm{~N}$ 塩酸で $p \mathrm{H}$ 2 3 に調整する。反応混合物を酢酸エチルで抽出 し，10\% 炭酸水素ナトリウム水溶液，ついで 水で洗浄後無水硫 酸マグネシウムで脱水する。減圧で酢酸エチルを留去すると，L-

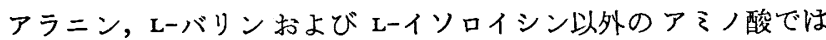
アクリロイルアミノ酸メチルエステルの結晶が析出するから，こ れをエチルエーテルーメタノール混合溶媒で 2〜3 回再結晶する。 L-バリンおよび L-イソロイシンの場合は重合禁止郕としてヒド ロキノンを加えてから減圧蒸留によって精製した。Lーアラニンは 蒸留中にきわめて重合しやすいので，さらに精製することなくそ のままオス之ウム酸エステルの合成に使用した。得られたアクリ ロイルアミノ酸メチルエステルの沸点, 比旋光度小よび元素分析 結果をつぎに示す。

アクリロイル-L-アラニンメチルエステル (Acr·L-Ala $\cdot \mathrm{OMe})$; $[\alpha]_{\mathrm{D}}^{8.0}-90^{\circ}(c=1, \times タ ノ ー ル) 。$

アクリロイル-L-バリンメチルエステル $(\mathrm{Acr} \cdot \mathrm{L}-\mathrm{Val} \cdot \mathrm{OMe})$; $\mathrm{bp}_{3} 102^{\circ} \mathrm{C},[\alpha]_{\mathrm{D}}^{21.5}-44^{\circ}(c=1$,メタノール)。

アクリロイル-L-ロイシンメチルエステル(Acr·L-Leu·OMe); $\operatorname{mp} 60.5^{\circ} \sim 61.2^{\circ} \mathrm{C},[\alpha]_{\mathrm{D}}^{24.0}-62.8^{\circ}(c=4$, メノール)。

分析值 C $60.40 \%, \mathrm{H} 8.65 \%, \mathrm{~N} 6.92 \%$

$\mathrm{C}_{10} \mathrm{H}_{17} \mathrm{NO}_{3}$ としての

計算值 C $60.26 \%, \mathrm{H} 8.61 \% ， \mathrm{~N} \mathrm{7.03 \%}$ アクリロイル-D-ロイシンメチルエステル(Acr·D-Leu.OMe); $\operatorname{mp} 60.5^{\circ} \sim 61.5^{\circ} \mathrm{C},[\alpha]_{\mathrm{D}}^{24.0}+61.9(c=4, \times タ ノ ー ル) 。$

分析值 $\mathrm{C} 60.38 \%, \mathrm{H} 8.61 \%, \mathrm{~N} 6.96 \%$

$\mathrm{C}_{10} \mathrm{H}_{17} \mathrm{NO}_{3}$ としての

計算值 C $60.26 \% ， \mathrm{H} 8.61 \% ， \mathrm{~N} \mathrm{7.03 \%}$

アクリロイル-L-イソロイシンメチルエステル (Acr·L-Ileu·O $\mathrm{Me}) ; \mathrm{mp} 121^{\circ} \sim 122^{\circ} \mathrm{C} / 3 \mathrm{mmHg},[\alpha]_{\mathrm{D}}^{26.0}-32.0(c=1$, メ夕 ノール)。

分析値 C $59.57 \%, \mathrm{H} 8.77 \%, \mathrm{~N} 7.08 \%$ $\mathrm{C}_{10} \mathrm{H}_{17} \mathrm{NO}_{3}$ としての

計算值 C $60.26 \%, \mathrm{H} 8.61 \%, \mathrm{~N} 7.03 \%$ アクリロイル-れーメチオニンメチルエステル(Acr $\cdot \mathrm{L}-\mathrm{Met} \cdot \mathrm{OMe})$; $\mathrm{mp} 51^{\circ} \sim 52^{\circ} \mathrm{C},[\alpha]_{\mathrm{D}}^{9.0}-40^{\circ}(c=1$, メタノール)。

分析值 C $49.91 \%, \mathrm{H} 7.15 \%, \mathrm{~N} 6.44 \%$ $\mathrm{C}_{9} \mathrm{H}_{15} \mathrm{NO}_{3} \mathrm{~S}$ としての

計算值 C $49.73 \%, \mathrm{H} 6.96 \%, \mathrm{~N} 6.45 \%$ アクリロイル-D-フェニルグリシンメチルエステル (Acr·D-

4) R. K. Kulkarini, H. Morametz, J. Polymer Sci., 54, $491(1961)$.
Phgly. OMe $) ; \mathrm{mp} 108^{\circ} \sim 109^{\circ} \mathrm{C},[\alpha]_{\mathrm{D}}^{24.0}-184.3^{\circ}(c=4$, メタノ ール)。

$\mathrm{C}_{12} \mathrm{H}_{13} \mathrm{NO}_{3}$ としての

分析値 C $65.85 \%, \mathrm{H} 6.07 \%, \mathrm{~N} 6.39 \%$

計算值 C $65.72 \% ， \mathrm{H} 5.98 \% ， \mathrm{~N} 6.39 \%$

アクリロイル-L-フェニルアラニンメチルエステル (Acr·L-Phe$\mathrm{OMe}) ; \operatorname{mp~} 86^{\circ} \sim 87^{\circ} \mathrm{C},[\alpha]_{\mathrm{D}}^{18.0}+11.5^{\circ}(c=4$, メタノール)。

分析值 $\mathrm{C} 67.14 \%, \mathrm{H} 6.62 \%, \mathrm{~N} 6.02 \%$ $\mathrm{G}_{13} \mathrm{H}_{15} \mathrm{NO}_{3}$ としての

計算值 C $66.92 \%, \mathrm{H} 6.49 \% ， \mathrm{~N} 6.01 \%$ アクリロイル-D-フェニルアラニンメチルエステル(Acr·D-Phe $\mathrm{OMe}) ; \operatorname{mp} 87^{\circ} \sim 88^{\circ} \mathrm{C},[\alpha]_{\mathrm{D}}^{24.0}-10.5^{\circ}(c=4$, メタノール)。

分析值 $\mathrm{G} 67.03 \%, \mathrm{H} 6.50 \%, \mathrm{~N} 6.06 \%$ $\mathrm{C}_{13} \mathrm{H}_{15} \mathrm{NO}_{3}$ としての

計算值 C $66.92 \% ， \mathrm{H} 6.49 \% ， \mathrm{~N} 6.01 \%$ 2.4 アクリロイル-( S )-aーフェネチルアミンの合成

2.3 .2 と同じ方法で 合成した。 $\mathrm{mp} 93.5^{\circ} \sim 96^{\circ} \mathrm{C},[\alpha]_{\mathrm{D}}^{24.0}$ $-180.9^{\circ}\left(c=4, \times\right.$ タノ一ル)。文献値 $\left.{ }^{5}\right) \mathrm{mp} 95.5^{\circ} \sim 96^{\circ} \mathrm{C},[\alpha]_{D}^{25}$ $-217.5^{\circ}$ (エタノール)。

分析值 C $75.63 \%, \mathrm{H} 7.68 \%, \mathrm{~N} 8.14 \%$ $\mathrm{C}_{11} \mathrm{H}_{13} \mathrm{NO}$ としての

計算值 $\mathrm{C} 75.38 \%, \mathrm{H} 7.48 \% ， \mathrm{~N} 8.00 \%$

2.5 アクリル酸誘導体 のオスミウム酸エステル(ピリジン 2 mol の付加物)の合成

Criegee らீ)の方法にしたがってつぎのようにして合成した。 精製したエチルエーテル $2 \sim 6 \mathrm{ml}$ に, $0.2 \mathrm{mmol}$ のアクリル酸 誘導体と $0.4 \mathrm{mmol}$ のピリジンを溶解する。乙れに $0.2 \mathrm{mmol}$ の酸化オスミウム(VII)を加えると，ただちに褐色の結晶あるいは 油状物を析出するから，乙れを約 24 時間室温に放置する。生成 物が絬晶である場合はロ別した結晶を少量のエチルエーテルで洗 浄したのちデシケーター中で乾燥する。アクリロイルー(S)- $\alpha$ フェネチルアミンのみはエチルエーテルに難溶であるから，溶媒 に酶酸エチルを朋いて酸化オス之ウム(䜣)を反応させたのち，nヘキサンを加えて結晶を析出させた。油状物が析出する場合はエ チルエーテル層を傾演し，さらにエチルエーテルで傾演をくり返 したのち, デシケーター中で乾燥して結晶化させた。オスミウム 酸エステルの収率はいずれも 80〜90\% で，減圧デシケーター中 では安定な褐色の粉末であるが，加熱すると徐々に分解黑变して 明確な融点を示さなかった。

\section{6 旋光分散曲線(ORD)の測定}

島津製作所製 QR-50 型光電分光光度計付属旋光分散測定装置 を用い， $5 \mathrm{~m} \mu$ の波長間隔で測定した。アクリル酸誘導体はメタ ノールを溶媒とし，濃度は $2 \sim 0.5 \mathrm{~g} / 100 \mathrm{ml}$ で測定した。オス ミウム酸エステルの測定には 0.4 vol\% のピリジを含むメタノ ールを溶媒として用い，浪度は 700〜 $400 \mathrm{~m} \mu$ の波長範囲では 1 $\mathrm{g} / 100 \mathrm{~m} l, 400 \mathrm{~m} \mu$ 以下は $0.25 \mathrm{~g} / 100 \mathrm{ml}$ で測定した。なお一部 について柳本自動揤録分光旋光計 ORD-185 型を用いて測定し， 両者が誤产範囲内で一致することを確認した。

5) G. Anzuino, M. d'Alagni, F. Quadrifoligo, Ric. Sci. Rend. Sez. A, 3(7), 957(1963); Chem. Abst., 60, 5329 (1964).

6) R. Criegee, B. Marchand, H. Wannowius, Ann., 550, $99(1942)$. 


\section{7 円二色性曲線 $(\mathbf{C D})$ の測定}

Roussel-Jouan Dichrographe を用い，ORD と同溶媒で 濃度 は $2 \mathrm{~g} / 100 \mathrm{~m} l$ とし, $0.5 \mathrm{~cm}$ セルを用いて測定した。

\section{8 吸収スペクトルの測定}

島津 QV-50 型光電分光光度計を用いて，ORD と同溶媒で測 定した。

\section{3 結果と考察}

アクリロイルアミノ酸メチルエステル,アクリロイル-L-バリン およびアクリロイルー(S)- $\alpha$-フェネチルアミンのオスミウム酸エ ステルピリジン付加物(以下簡単のためオスミウム酸エステルと 省略する)はいずれも $440 \mathrm{~m} \mu$ 付近に分子吸光係数 130 程度の極 大あるいは肩を有する吸収曲線を示し，さらにこれより長波長側 に幅広い吸収带を有している。図 1 から明らかなようにアクリ口 イル-Lーメチオニンメチルエステルのオスミウム酸エステル(Acr. L-Met.OMe-Os[ 7 )の ORD は $610 \mathrm{~m} \mu$ 付近に肩を持ち, 523

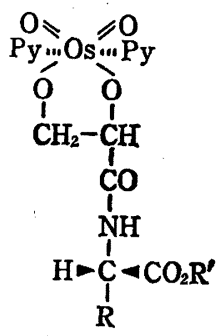

L-系フミノ酸誘導体

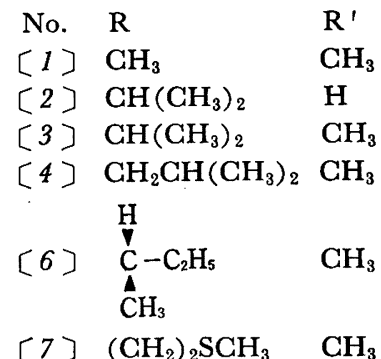

[9] $\mathrm{CH}_{2} \mathrm{C}_{6} \mathrm{H}_{5} \quad \mathrm{CH}_{3}$

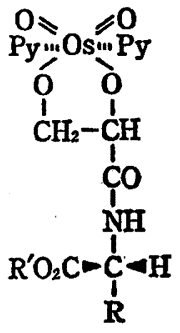

$\mathrm{D}$-系厂ミノ酸誘導体

No. $\mathrm{R} \quad \mathrm{R}^{\prime}$

[5] $\mathrm{CH}_{2} \mathrm{CH}\left(\mathrm{CH}_{3}\right)_{2} \mathrm{CH}_{3}$

[8] $\mathrm{C}_{6} \mathrm{H}_{5} \quad \mathrm{CH}_{3}$

[10] $\mathrm{CH}_{2} \mathrm{C}_{6} \mathrm{H}_{5} \quad \mathrm{CH}_{3}$

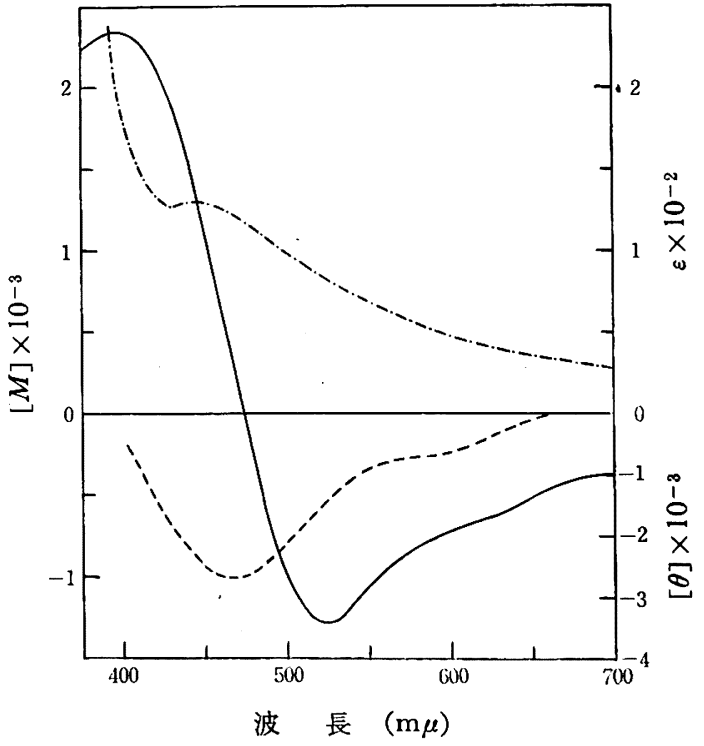

図 $1 \mathrm{Acr} \cdot \mathrm{L}-\mathrm{Met} \cdot \mathrm{OMe}-\mathrm{Os}[7]$ ORD $(-), \mathrm{CD}(---)$ および吸収スペクトル(-・-・) $\mathrm{m} \mu$ に谷を, $400 \mathrm{~m} \mu$ に山をもった複合 Cotton 効果を示し, こ れは Djerassi ら²)よって報告されたコレステン類のオスミウム 酸エステルのピリジン付加物のそれときわめて類似している。吸 収スペクトルからはこの Cotton 効果に対応した明確な光学活性 吸収帯を知ることはできないが，〔7〕の CD が $590 \mathrm{~m} \mu$ 付近に 負の肩を, $460 \mathrm{~m} \mu$ により大きい負の極大を示すことから，この 複合 Cotton 効果が 590 と $460 \mathrm{~m} \mu$ とに変曲点をむった二つの Cotton 効果からなることが明らかである。

種々の脂肪族 $\alpha-ア$ そ酸誘導体のオス之ウム酸エステル([1] 〜 [6])の ORD を図 2 および図 3 に示すが, 振幅の大きさはアる ノ酸の種類によって異なるが形はまったく類似した 複合 Cotton 効果を示している。また図 2 から明らかなように遊離のアクリロ

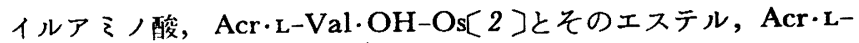
Val.OMe-Os[3]との ORD にはまったく差異が認められなか った。

なおオスミウム酸エステルの ORD， CD および吸収スペクト ルの測定を少量のピリジンを含むメタノールを溶媒として用いた のは，これらの化合物が結晶状態では安定であるが，メタノール 溶媒中では 20３0 分間で分解黒変するのでこれを防ぐためであ る。たとえば $0.4 \mathrm{vol} \%$ のピリジンを加えたメタノールを用い ると，少なくとも 4 時間は 700〜 $400 \mathrm{~m} \mu$ の吸収スペクトルに変 化がまったく認められなかった。またピリシンを加えない場合は ORD の測定中に変色するが, Acr·L-Val·OH〔 2 〕と Acr-L-Leu • OMe-Os[4]では 700〜 $500 \mathrm{~m} \mu$ の範囲で測定が可能であり，得 られた曲線はピリジンを加えた場合と誤差範囲内で一致した。

つぎに複合 Cotton 効果の符号を見ると，図 2 および図 3 から 明らかなように L-系アミノ酸誘導体([1]〜[4], [6], [7])の それはすべて負である。しかも図 3 の Acr.D-Leu·OMe-Os[5] にみられるように D-系のそれは L-系[4]とはまったく対称的な 曲線を示している。これはオスるウム酸エステルの Cotton 効果 の符号をアミノ酸の $\alpha$-不整中心の絶対配置と関係うけうること を示している。また[4]と Acr·L-Ileu·OMe-Os[6]の ORD が 形，振幅ともよく類似しているのも興味ある事実である。同様な

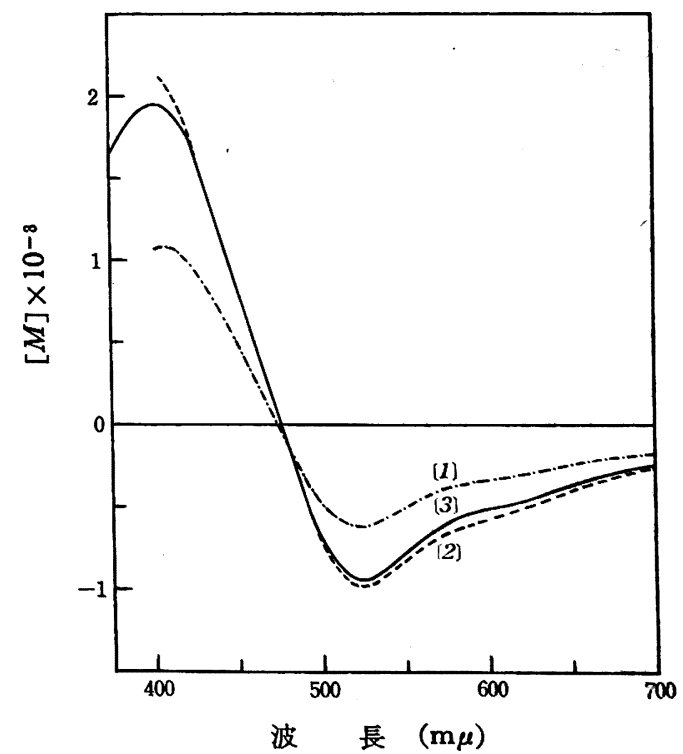

四 $2 \mathrm{Acr} \cdot \mathrm{L}-\mathrm{Ala} \cdot \mathrm{OMe}-\mathrm{Os}[1], \mathrm{Acr} \cdot \mathrm{L}-\mathrm{Val} \cdot \mathrm{OH}-\mathrm{Or}[2]$ および Acr·L-Val·OMe-Os[ 3$]$ の ORD 


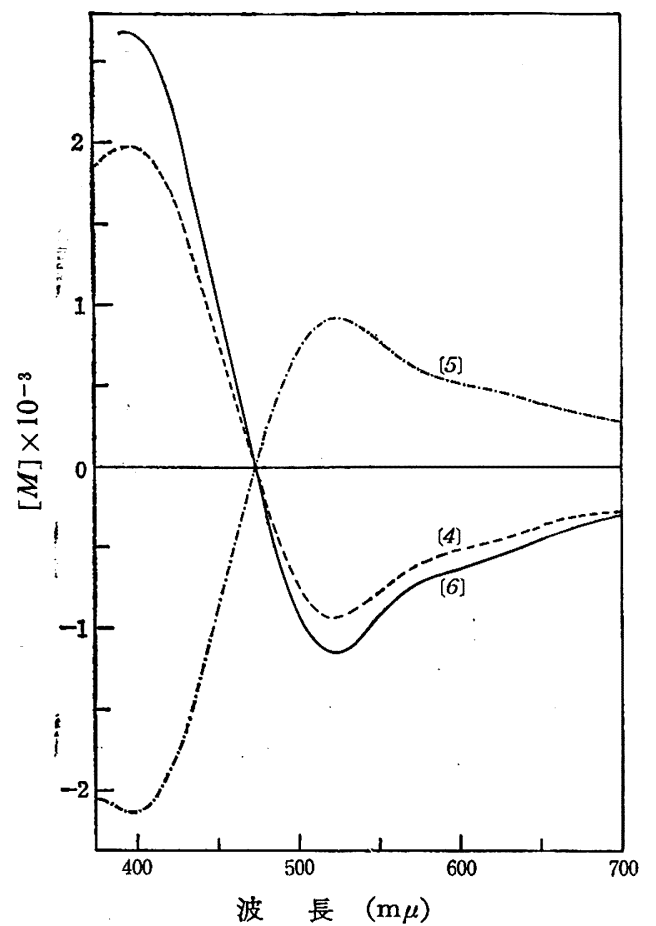

四 $3 \mathrm{Acr} \cdot \mathrm{L}-\mathrm{Leu} \cdot \mathrm{OMe}-\mathrm{Os}[4]$, Acr $\cdot \mathrm{D}-\mathrm{Leu} \cdot \mathrm{OMe}-\mathrm{Os}$ [5]および Acr·L-Ileu.OMe-Os[6]の ORD

現象はアミノ酸の $N$-ジチオカルバマートワにおいても報告され， イソロイシンの $\beta$-不整炭素が ORD におよぼす影響の少ないこ とを示している。

図 4 にフェニル核を含んだ $\alpha$-アミノ酸誘導体([8]〜[10])の ORD および[9]の CD を示した。Acr·D-Phgly·OMe-Os[8] の ORD は脂肪族アミノ酸と同じ形をもった複合 Cotton 効果 を示し，その符号は正であるから脂肪族アミノ酸に見られる関係 と一致している。しかし Acr-Phe·OMe-Os([9],[10])では複 合 Cotton 効果と考元られる曲線の符号は L-系[9]では正，D和 10$]$ では負であって,上の一般則とは逆の関係にある。図 4 に おいて[9]の CD の長波長側の極大は強度が小さくて明確でな いが，460 $\mathrm{m} \mu$ の極大は明らかに正で ORD の結果を裹ゔけるも のである。このような異常性は芳香族アミノ酸や環式アミノ酸に

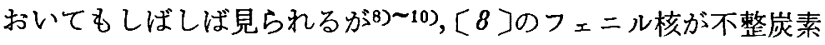
に直接ついているにもかかわらず脂肪族アるノ酸とまったく類似 した関係にあることから，フェニル核の電子遷移が ORD に影 響しているとは考えにくく空間的な配置による影響と考えられ る。

アミノ酸以外にも図 4 に示すようにアクリロイル-(S)- $\alpha$-フ エネチルアミンのようなアミン誘導体のオスミウム酸エステル 〔11〕についても同様な複合 Cotton 効果が見られ，その符号は負 であった。Cahn-Ingold-Prelog の RS 命名法によれば，L-系ア ミノ酸の絶対配置は S であるから，〔11〕の Cotton 効果の符号も

7) B. Sjöberg, A. Fredga, C. Djerassi, J. Am. Chem. Soc., 81, 5002(1959).

8) C. Djerassi, H. Wolf, E. Bunnenberg, ibid., 84, 4552 (1962).

9) H. Wolf, E. Bunnenberg, C. Djerassi, Chem. Ber., 97, 533(1964).

10) V. Tortorella, G. Bettoni, Chem. Commun., 1967, 321.

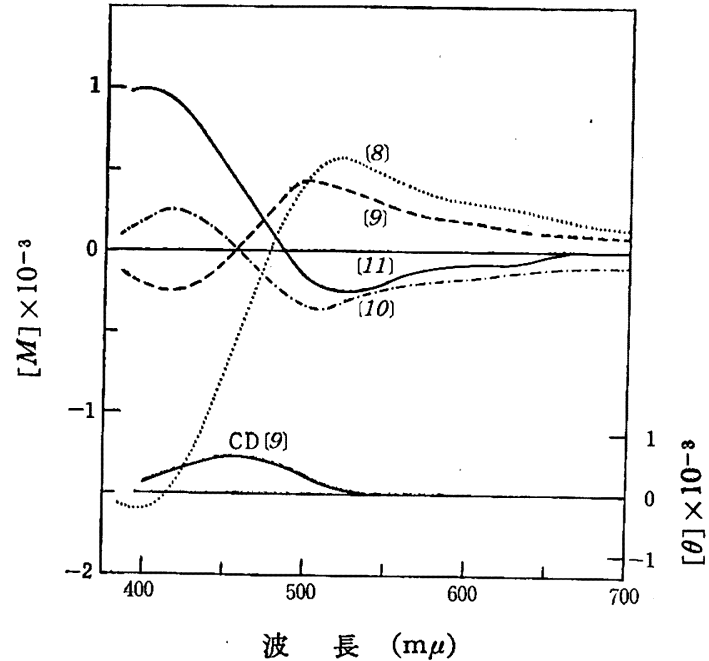

図 4 Acr $\cdot \mathrm{D}-\mathrm{Phgly} \cdot \mathrm{OMe}-\mathrm{Os}[8]$, Acr $\cdot \mathrm{L}-\mathrm{Phe} \cdot \mathrm{OMe}-\mathrm{Os}[9]$ Acr.D-Phe·OMe-Os〔10]およびフクリロイルー $(\mathrm{S})-$ $\alpha$ ーフェネチルナミン〔11]のIORD，および〔9]の!CO

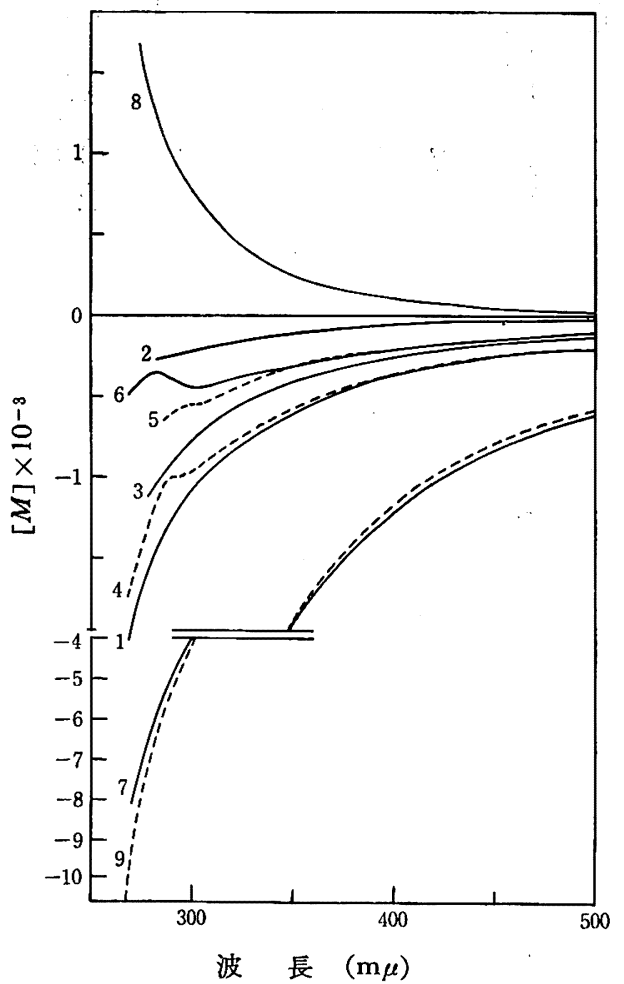

1: Acr $\cdot \mathrm{L}-\mathrm{Ala} \cdot \mathrm{OMe}, 2: \mathrm{Acr} \cdot \mathrm{L}-\mathrm{Val} \cdot \mathrm{OH}$, 3: Acr $\cdot \mathrm{L}-\mathrm{Val} \cdot \mathrm{OMe}, \quad 4: \mathrm{Acr} \cdot \mathrm{L}-\mathrm{Leu} \cdot \mathrm{OMe}$, $5:$ Acr $\cdot \mathrm{L}-\mathrm{Ileu} \cdot \mathrm{OMe}, 6: \mathrm{Acr} \cdot \mathrm{L}-\mathrm{Met} \cdot \mathrm{OMe}$, 7: Acr $\cdot \mathrm{D}-\mathrm{Phgly} \cdot \mathrm{OMe}, 8: \mathrm{Acr} \cdot \mathrm{L}-\mathrm{Phe} \cdot \mathrm{OMe}$,

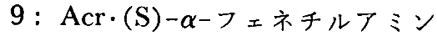

因 5 アクリル酸誘導体の ORD

一般則に一致しているといわねばならない。

図 5 にアクリロイルア之ノ酸メチルエステル,アクリロイル-L-

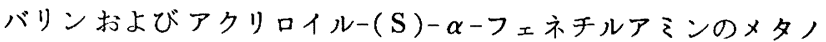
ール中での ORD を示した。四から明らかなように Acr·L-Leu・ $\mathrm{OMe}$, Acr-L-Ileu·OMe および Acr·L-Met·OMe(曲線 4, 5 および 6 )は $290 \mathrm{~m} \mu$ に異常性を示す。これら 3 種の化含 
物のメタノール中での $290 \mathrm{~m} \mu$ での分子吸光係数はいずれも 10 以下で，その付近に極大が認められず， $225 \mathrm{~m} \mu$ に分子吸光係数 9000 程度の肩が存在するのみであるから，この ORD の異常性 の原因となっている光学活性吸収帯は明らかでない。Anzuino

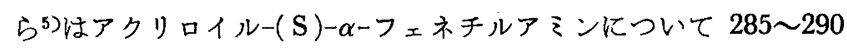
$\mathrm{m} \mu$ に Cotton 効果の存在することを報告しているが，著者らの 実験ではメタノール溶媒中で $260 \mathrm{~m} \mu$ までに 異常性が 認められ なかった。なおアクリル酸誘導体の単純曲線の符号と相当するオ スミウム酸エステルの Cotton 効果の符号とは, フェニルグリシ ン以外は一致していることが認められた。

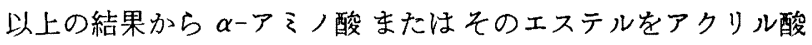

誘導体のオスそウム酸エステルにすることにより，比較的測定容 易な長波長領域に背景曲線の影響をほとんど受けない Cotton 勃 果曲線が得られ，アミノ酸の絶対配置をその符号と相関させうる ことを知ったが, 二重結合への酸化オスミウム(V)の付加によっ て生ずる 2 種のジアステレオマーの生成割合とアクリロイル誘導 体の立体構造との関係については今後十分な検豇が行なわれる必 要があると考える

本研究の費用の一部は, 文部省科学研究費によったととを付記 し感謝致します。また試料のフミノ酸を御供与いただいた米山薬 品工業株式会社に感謝致します。

(1966 年 4 月, 日本化学会第 19 年会講演)

\section{アルキルおよびアリールシアナートの光化学反応}

(昭和 42 年 5 月 11 日受理)

原 三干雄*1 ${ }^{*}$ 藤本 豪*2 $\cdot$ 大平 愛信*1 $\cdot$ 堤

繁*1

シフナート類の光化学的挙動を知るために，各種溶媒中でフルキル拈よびフリールシフナートの光照射を試みた。エチルおよび n-プチルシフナートなどのアルキルシフナートにおいては光異性化が優先し，イソシフナートおよびその三量体であるインシדヌ ラートが得られた。また光分解生成物としては，少量のアルコール，フルデヒド，エステルおよびウレタンが確認されたが，シて ン化物の生成はまったく認められなかった。さらにフェニルおよび oートリルシフナートは，多量の環化三量体に加えるとフェノ 一ル(または 0 -クレゾール)，o-および p-シフノフェノール(または 2-メチル-6-シフノフェノールおよび 2-メチルー4-シフノフ ェノール）を与えたが，異性化物は認められなかった。一方，2,6-ジ-t-ブチルフェニルシフナートの場合には $t$-ブチル基の大きな

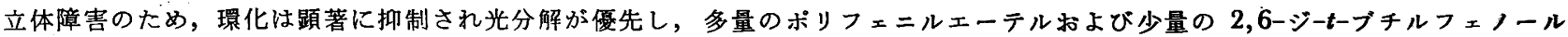
と4-シフノ-2,6-ジーt-ブチルフェノールが得られた。また，光異性化および光脱ブチル化も認められた。以上の実験結果に基うい て反応の諸過程を検討した。

\section{1 緒 論}

種々のシアナート類が最近合成されるようになったことは周知 のとおりであるが1)，有機ニトリトやハイポハライトとの関連に おいてその光化学的挙動がとくに興味がもたれるが2), シアナー 卜類の光化学反応に関する研究はいまだ報告されていない。著者 らはシアナート類の光化学反応挙動を知る基礎的研究の一環とし て, すでに $n$-ブチルシアナートの気相光分解において光異性化 が優先し, 少量ながら R-OCN, RO-CN 結合開裂が起ること を報告したが3，本報においては既報において記載された知見に 基づいて溶液中でのアルキルおよびアリールシアナートの光化学 反応を試みた。とくにシアナート類の光環化反応, 光異性化反応

*1 Michio Hara, Yoshinobu Odarra, Shigeru Tsutsum 大阪大学工学部応用化学教室, 大阪市都島区東野田

*2 Takeshi Fujıмото 現在 出光興産株式会社千葉製油所, 市原市姉崎

1) a) K. A. Jensen, A. Holm, Acta Chem. Scand., 18, 2417 (1964).

b) K. A. Jensen, M. Due, A. Holm, ibid., 19, 438 (1965).

c ) D. Martin, W. Mucke, Ber., 98, 2059(1965).

d) E. Grigat, R. Pütter, ibid., 97, 3012(1964).

e ) J. G. Kauer, W. W. Henderson, J. Am. Chem. Soc., 86, 4732(1964).

2) M. Akhtar, "Advances in Photochemistry", Interscience Pub. Inc., New York(1964)Vol. 2, p. 263.

3) M. Hara, Y. Odaira, S. Tsutsumi, Tetrahedron Letters, 1967, 1641.
および光分解反応におよほす置換基効果を知るために，シアナー トとしてェチル，nーブチル，フェニル， ○ートリルおよび 2,6ジー $t$-ブチルフェニルシアナートを選び, 高圧水銀灯外部照射下 に反応を行ない，それぞれの生成物の生成過程に検討を加えた。

\section{2 実酫}

\section{1 試 料}

エチルおよび $n$-ブチルシアナート: Jensen らの方法 ${ }^{1 a}$ により アルキルチオカルバマートを黄色酸化水銀で分解し合成した。

$$
\begin{array}{llll}
\text { エチルシフナート } & n_{\mathrm{D}}^{22} & 1.3760 \text {, 収事 } & 40 \% \\
n \text {-ブチルシフナート } & n_{\mathrm{D}}^{22} & 1.4000 \text {, 収事 } & 35 \%
\end{array}
$$

フェニルおよび o-トリルシアナート: Grigat らの方法1dによ りトリエチルアミン存在下, フェノールと塩化シアンの反応によ り合成した。

$$
\begin{aligned}
& \text { フェニルシナナート } \\
& \mathrm{bp}_{2} \quad 38^{\circ} \sim 40^{\circ} \mathrm{C}, n_{\mathrm{D}}^{22} \quad 1.5190 \text {, 収事 } 80 \% \\
& \text { ○ートリルシアナート } \\
& \mathrm{bp}_{2} \quad 65^{\circ} \sim 68^{\circ} \mathrm{C}, n_{\mathrm{D}}^{18} \quad 1.5193 \text {, 収事 } 90 \%
\end{aligned}
$$

2,6-ジ-tーブチルフェニルシアナート: Stroh らの方法りより

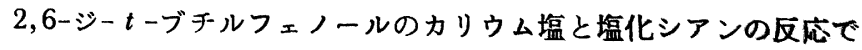
合成した。

$\mathrm{bp}_{2} \quad 98^{\circ} \sim 100^{\circ} \mathrm{C}, \mathrm{mp} \quad 48^{\circ} \sim 52^{\circ} \mathrm{C}$ (石油エーテル)

\section{2 エチルシアナートの光分解}

エチルシアナート $12.0 \mathrm{~g}(0.158 \mathrm{~mol})$ とエチルエーテル $100 \mathrm{ml}$

4) R. Stroh, H. Gerber, Angew. Chem., 72, 1000(1960), 